ノート

落葉病抵抗性であん色が紫色のアズキ新品種「紫さやか」の育成

長岡寛知 ${ }^{1,2)}$ ・ 山田宗平 3) ・ 小河俊郁 3) ・ 長岡泰良 ${ }^{2)}$

1) 帯広畜産大学, 北海道帯広市, $=080-8555$

2) 株式会社バイオテック，北海道河西郡芽室町，干 082-0005

3) 株式会社御座候，兵庫県姫路市， $=670-8654$

\title{
Breeding of a new adzuki bean variety "Murasaki-sayaka" with resistance to brown stem rot and purple colored bean paste
}

Hirokazu Nagaoka ${ }^{1,2)}$, Sohei Yamada ${ }^{3)}$, Toshifumi Ogawa ${ }^{3)}$ and Yasuyoshi Nagaoka ${ }^{2)}$

1) Obihiro University of Agriculture and Veterinary Medicine, Obihiro, Hokkaido 080-8555, Japan

2) Biotech Co., Ltd., Memuro-cho, Kasai-gun, Hokkaido 082-0005, Japan

3) Gozasoro Co., Ltd., Himeji, Hyogo 670-8654, Japan

キーワード

Vigna angularis，アズキ，品種，落葉病，あ九色，機械化適性

\section{育成の背景}

近年，北海道のアズキ (Vigna angularis (Willd.) Ohwi et Ohashi）の栽培面積は 20,000 ha 前後で推移し, その生産 量は全国の約 $80 \%$ を占めている（農林水産省 2018）。北 海道の基幹品種「エリモショウズ」（村田ら 1985）は, 耐冷性が強く多収性であるだけでなく，実需者からはあ 几の風味と色が良く, 加工適性が優れることが評価され， 1995 年には全道作付け比率は $87 \%$ を占めたが，2017 年 は33\%まで減少している（北海道農政部 2019）。本品種 は北海道のアズキ栽培における重要病害の一つであるア ズキ落葉病（Cadophora gregata f. sp. adzukicola）（以下， 「落葉病」）の抵抗性を備えていないため，病害発生で大 きく減収することがある。落葉病は 1970 年代に主産地の 十勝地方で大発生し, 多発年には罹病率が全道のアズキ 栽培面積の $50 \%$ 前後まで達した. 生育初期の罹病が原因 で 50\% 以上も減収する（藤田 2007）。病害抵抗性品種の 導入と長期輪作の励行により, 現在の罹病率は $5 \%$ 程度 まで減少している。2 000 年に育成された品種「しゅま り」（藤田ら 2002）は, 落葉病に加えて, 茎疫病 (Phytophthora vignae f. sp. adzukicola) と萎调病 (Fusarium oxysporum f. sp. adzukicola）への抵抗性が強く，あん色が 紫色で関西地域の大手和菓子メーカーからは,「エリモ

編集委員 : 友岡憲彦

2019 年 3 月 11 日受領 2020 年 1 月 14 日受理

2020 年 2 月 15 日 J-STAGE 早期公開

Correspondence: hiro-biotech@cpost.plala.or.jp
ショウズ」よりも優れると評価を得た。 しかし, 開花時 の低温あるいは高温による不稔が発生し, 安定的な収量 を確保できないことが問題となって，2017年の全道作付 け比率は $3 \%$ となっている.

北海道に括ける，アズキの高い作付面積の維持と収量 の安定性, 品質には品種育成の寄与が大きく, 今後も新 品種の開発が期待されている. 北海道十勝地方のアズキ 品種が具備すべき形質として, 耐冷性, 収量性, 味や香 りなどの風味やあん色, 打よび煮熟性などの加工適性, 落葉病の抵抗性が挙げられる。また，現在の栽培体系は 省力化が望まれて捜り，機械化適性の向上も欠かせない. 筆者らは，これらの条件を満たす品種「紫さやか」を育 成した.

\section{育成経過}

交配母本には中生, 耐冷性“中”，安定多収で加工適 性の高い「エリモショウズ」を母とし, 中生, 耐冷性 “弱”，落葉病菌レース 1 と 3 抵抗性で紫色のあん色と なる「しゅまり」を父として選定した（図 1)。育成経過 は以下の通りである。

2006 年に北海道芽室围場において上記組合せ 20 花の 交配を行い， 37 粒の $\mathrm{F}_{1}$ 種子を得た。2007 年 1 月から 5 月に沖縄県宮古島市に扮いて $F_{1}$ 世代を養成し, 着萊した 個体から 171 粒の $F_{2}$ 種子を得た。 2007 年 $\left(F_{2}\right.$ 世代）と 2008 年 $\left(\mathrm{F}_{3}\right.$ 世代) は, 北海道清水町の落葉病抵抗性現地 選抜围場で耐病性検定を行い, 耐病性の $\mathrm{F}_{3}$ 世代 11 系統 


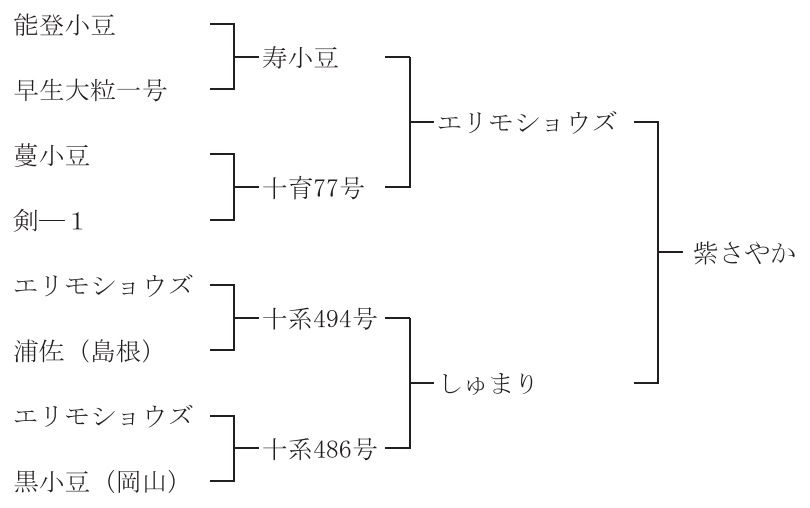

図 1.「紫さやか」の系譜. 「浦佐」,「黒小豆」は在来種.

102 個体を選抜した。 2009 年（ $\mathrm{F}_{4}$ 世代 102 系統を栽培） から 2011 年 $\left(\mathrm{F}_{6}\right.$ 世代 109 系統を栽培) までは, 北海道清 水町の健全戋場で生育特性と収穫種子の外観品質の調査 による系統選抜を繰り返した。

2012 年 $\mathrm{F}_{7}$ 世代から 2014 年 $\mathrm{F}_{9}$ 世代では, 選抜された系 統の種子を 2 群あるいは 3 群に分けて, 一方の種子は清 水町の健全圃場での生育特性による選抜を，もら一方の 種子は北海道幕別町駒畠地区の耐冷性検定戋場での選抜 を行った。北海道幕別町は，アズキの栽培が可能な下限 温度地帯であり，6月～9 月の平年の積算気温が $1950^{\circ} \mathrm{C}$ (農研機構メッシュ農業気象データ) である。 $\mathrm{F}_{8}$ 世代と $\mathrm{F}_{9}$ 世代では北海道芽室圃場でも栽培を行い，そこで収穫 された種子を用いて煮熟試験と粒あんの官能試験による 加工適性試験で選抜した。 これらの試験結果を総合的に 判断して, 後に「紫さやか」になる 1 系統「BT 252 号」 を $\mathrm{F}_{9}$ 世代に選抜した。

2015 年（ $\mathrm{F}_{10}$ 世代）から 2017 年（ $\mathrm{F}_{12}$ 世代）には, 「BT 252 号」を用いて北海道清水町の落葉病抵抗性現地選抜 圃で耐病性を，幕別町駒畠地区で耐冷性を検定した。落 葉病現地選抜戋場に抢ける「BT252 号」の罹病率は $0 \%$ であった．落葉病抵抗性については 2017 年にレース 1 と 3 の抵抗性の判別マーカーPg118を用いた DNA マーカー 検定（Suzuki et al. 2013）も実施し，「BT252 号」が「しゅ まり」に由来する落葉病抵抗性遺伝子型を示すことを明 らかにした（図 2）。また，北海道十勝地方に抢汀現地 栽培試験として，2016年（ $\mathrm{F}_{11}$ 世代）に 10 戋場で，2017 年（ $\mathrm{F}_{12}$ 世代）に 9 固場で「エリモショウズ」を対照品種 とする地域適応性の評価を行った。それらの結果をまと め,「BT 252 号」を「紫さやか」と命名して，2018 年 4 月に農林水産省へ品種登録出願（出願番号 33087）乙同 年 9 月に出願公表された.

\section{形態的および生態的特性（芽室圃場における生 産力検定）}

育成地である芽室圃場における 2014 年から 2016 年の

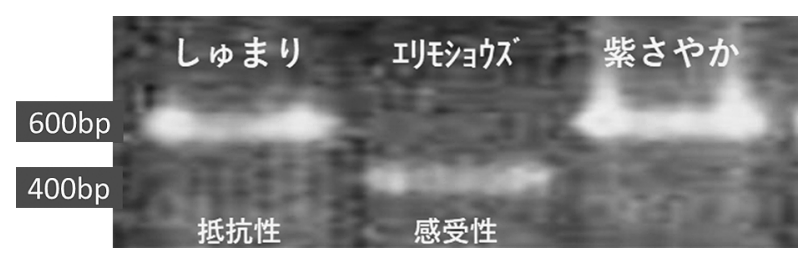

図 2. Pg118（Pga1 判別マーカー）を利用した検定結果. 「しゅまり」(左),「エリモショウズ」(中), 「紫さやか」(右). 3 個体の初生葉から DNAを抽出した。 2017 年芽室町産

慣行栽培による生産力検定の結果を示した（表 1)，生態 型は夏アズキ型で, 開花始, 抢よび成熟期は「エリモショ ウズ」並であった，主茎長は「エリモショウズ」よりや や長く, 主茎節数, 分枝数, 萊数, 打よび一萊内粒数は 同品種並であった。肧軸長（地表面から初生葉節までの 長さ）は同品種の $2.7 \mathrm{~cm}$ に対して有意に長く $6.3 \mathrm{~cm}$ で あった（表 1, 図 3)。倒伏抵抗性は倒伏程度が「エリモ ショウズ」より少ないことから，“強”と判定された。

落葉病抵抗性は, 2015 年から 2017 年の清水町現地選 抜検定圃場試験の結果から“強”之判定された（表 2). 2015 年から 2017 年の幕別町駒畠地区耐冷性現地選抜围 場（低温区）と芽室圃場（標準区）による生育比較から， 耐冷性の指標（a/b 比）は「エリモショウズ」並で “耐冷 性中”と判定された（表3）。

\section{芽室圃場における収量および品質特性}

芽室圃場に抢ける 2014 年から 2016 年の平均 $10 \mathrm{a}$ 子実 重は $311 \mathrm{~kg}$ となり，「エリモショウズ」より $11 \mathrm{~kg}$ 多収で あった（表 4)。百粒重は $15.2 \mathrm{~g}$ と普通小豆規格の範囲内 で，「エリモショウズ」より $1.9 \mathrm{~g}$ 重かった。原粒種皮色 について，色相角 $\left(\mathrm{h}^{\circ}\right)$ は「エリモショウズ」より小さ く,「しゅまり」並となり赤みが強い種皮色と判断され た. 加工適正の要素である粒あん色については, 明度 (L*) は「エリモショウズ」より高く，「しゅまり」並と なり，色相角 $\left(\mathrm{h}^{\circ}\right)$ は「エリモショウズ」より低く,「しゅ まり」並となったことから，明るい紫色の粒あん色と判 断された（表 5)。煮熟増加比，こしあ几の製あ几歩留和 よび煮え屯ら率は「エリモショウズ」並であった。 あん 粒子径は同品種よりやや大きかった，粒あんの味，香り， 色，種皮の硬さを，「エリモショウズ」を 3 として，4名 のパネラーによって 5 段階評価した官能評価の結果，「エ リモショウズ」に対しやや優る結果となった。

\section{十勝地方における現地栽培試験}

現地栽培試験は十勝地方を 2 地帯に分け, 2016 年から 2017 年の 2 年間, 計 19 か所の戋場で実施した（表 6). 十勝中央部の早生・中生種栽培地帯は 6 月から 9 月の積 算平均気温が $2100^{\circ} \mathrm{C}$ 以上で無霜期間が 130 日以上の地 
表 1. 芽室圃場における「紫さやか」および比較品種の生育調査成績（2014～2016，3 3 年の試験の平均值）

\begin{tabular}{|c|c|c|c|c|c|c|c|c|c|c|c|c|}
\hline 品種名 & $\begin{array}{c}\text { 開花始 } \\
(\text { 月日) }\end{array}$ & $\begin{array}{c}\text { 成熟期 } \\
\text { (月日) }\end{array}$ & $\begin{array}{c}\text { 主茥長 } \\
(\mathrm{cm})\end{array}$ & $\begin{array}{c}\text { 主茥節数 } \\
\text { (節) }\end{array}$ & $\begin{array}{l}\text { 分枝数 } \\
\text { (本/株) }\end{array}$ & $\begin{array}{c}\text { 莢数 } \\
\text { (萊/株) }\end{array}$ & $\begin{array}{c}\text { 一萊内 } \\
\text { 粒数 (粒) }\end{array}$ & $\begin{array}{c}\text { 胚軸長 } \\
(\mathrm{cm})\end{array}$ & $\begin{array}{l}\text { 落葉病 } \\
\text { 抵抗性 }\end{array}$ & 耐冷性 & $\begin{array}{l}\text { 倒伏 } \\
\text { 程度 }\end{array}$ & $\begin{array}{c}\text { 倒伏 } \\
\text { 抵抗性 }\end{array}$ \\
\hline 紫さやか & 7.25 & 9.23 & 71 & 14.2 & 3.5 & 47 & 6.18 & $6.3^{\mathrm{a}}$ & 強 & 中 & $0.8^{\mathrm{a}}$ & 強 \\
\hline エリモショウズ & 7.25 & 9.23 & 64 & 13.8 & 3.5 & 45 & 6.34 & $2.7^{\mathrm{b}}$ & 弱 & 中 & $2.7^{\mathrm{b}}$ & 中 \\
\hline しゅまり & 7.26 & 9.24 & 68 & 14.1 & 3.6 & 42 & 6.22 & $5.1^{\mathrm{ab}}$ & 強 & 弱 & $2.5^{\mathrm{b}}$ & 中 \\
\hline
\end{tabular}

1 区 $7.9 \mathrm{~m}^{2}$, 乱塊法 3 反復, 栽植密度は $66 \times 20 \mathrm{~cm}, 2$ 本立て, 15,152 本 $/ 10 \mathrm{a}$ とした.

倒伏程度は無 0 , 微 0.5 , 少 1 , 中 2 , 多 3 , 甚 4 で評価した.

分散分析で年次と年次 $\times$ 品種の交互作用がない形質について，3 品種群の多重比較（Tukey-Kramer 法）を行い，有意差を数值の右上付 き文字（a,b）で示した.

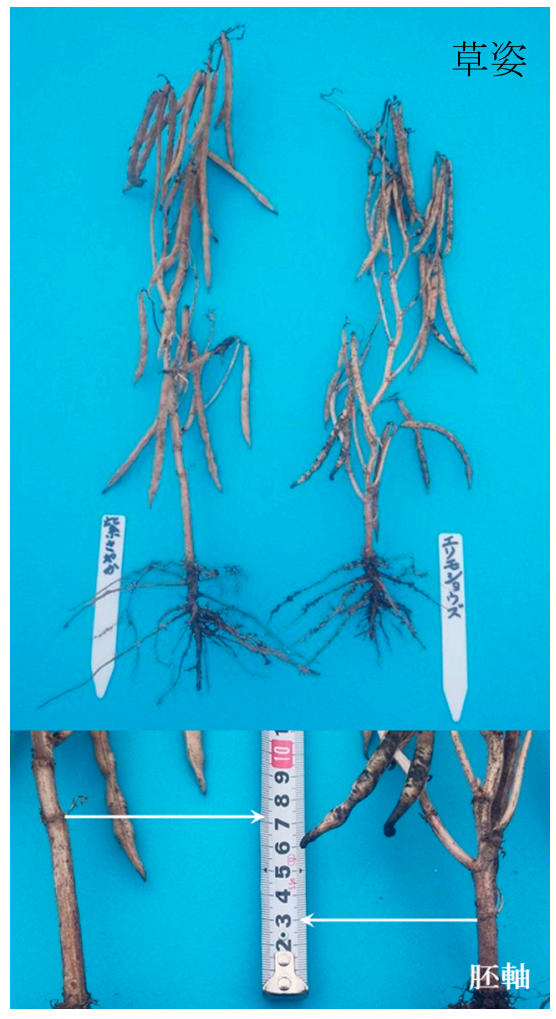

図 3.「紫さやか」の草姿と肧軸長.

「紫さやか」(左),「エリモショウズ」(右).

2017 年芽室町産

帯, 中央部を除いた十勝地方の早生種栽培地帯は同期間 の積算平均気温が $2000^{\circ} \mathrm{C}$ 前後で無霜期間が 130 日未満 の地帯である。両地帯に拈いて，「紫さやか」が「エリモ ショウズ」より有意に高い耐倒伏性を示し，百粒重が有 意に重く，あん粒子径が有意に大きかった以外は，両品 種はほほ注同等の生育・加工特性を示した.

\section{考察}

北海道の主要アズキ栽培地帯における栽培試験の結果 から，「紫さやか」は「エリモショウズ」に匹敵する収量 の安定性が確保できると考えた。

「紫さやか」は落葉病菌レース 1 と 3 の落葉病抵抗性を 備えて扣り, 病害の発生が懸念される圃場でアズキの作
付けが可能となる。「エリモショウズ」は落葉病の罹病発 生の危険回避のため 8 年程度の輪作間隔が必要となるが, 抵抗性品種の「紫さやか」は輪作の間隔をより短くでき る可能性がある（千葉 1987）。また，落葉病抵抗性品種 「しゅまり」の弱点であった耐冷性は，「紫さやか」では 「エリモショウズ」と同等に高くなっていた.

「紫さやか」の粒あん色は，「しゅまり」同様に明るい 紫色となっている. このあん色は上品な色（畑井 1987） であると, 実需者からの評価が大変高く, 今後北海道産 アズキの新しい需要が期待できる、味と香りや豆の煮え やすさ等の加工適正は「エリモショウズ」と浪同等で あり，北海道産アズキの良質な風味を維持できたことが 確認された。「紫さやか」のあん粒子径は,「エリモショ ウズ」よりもやや大きくなったが, 官能試験による評価 結果から，皮の硬さが軟らかく舌触りに影響のないこと が確認された。

百粒重は，「紫さやか」（15.2 g) が交配親の「エリモ ショウズ」(13.3 g) や「しゅまり」(14.2 g) よりも重く なった。北海道では, 近年, 高温登熟年が多くアズキの 小粒化による検査等級の低下が問題となっている。「紫さ やか」は普通小豆規格の中でも大粒であることから，こ の問題を軽減できる可能性がある.

「紫さやか」は「エリモショウズ」より耐倒伏性が強 く，胚軸長も長いことで最下着萊節高が高くなることか ら, 収穫時の機械化適性の向上が期待できる（島田 2009). 今後はこれらの形質について検証を重ねるととも に，関与する QTL を特定する予定である.

\section{謝 辞}

「紫さやか」の育成にあたり，現地栽培試験をご協力頂 いた取引先機関の担当者各位には，厚く御礼を申し上げ ます。

また，本稿のご指導とご校閲を頂いた，带広畜産大学 環境農学研究部門植物生産科学分野の加藤清明教授に感 謝の意を表する. 
表 2.「紫さやか」の落葉病現地選抜圃に扮ける試験成績およびレースに対する抵抗性

\begin{tabular}{|c|c|c|c|c|c|}
\hline \multirow{2}{*}{ 品種名 } & \multicolumn{3}{|c|}{ 落葉病罹病率（\% ） } & \multirow{2}{*}{ 落葉病レース $1 \cdot 3$ ヘの反応 } & \multirow{2}{*}{ 抵抗性区分 } \\
\hline & 2015 & 2016 & 2017 & & \\
\hline 紫さやか & 0 & 0 & 0 & $\mathrm{R}$ & 強 \\
\hline エリモショウズ & 100 & 100 & 100 & S & 弱 \\
\hline しゅまり & 0 & 0 & 0 & $\mathrm{R}$ & 強 \\
\hline
\end{tabular}

試験は，北海道清水町の落葉病抵抗性現地選抜圃場に打いて実施した.

1 区 $1.7 \mathrm{~m}^{2}$, 乱塊法 3 反復, 栽植密度は $66 \times 10 \mathrm{~cm}, 1$ 本立てとし, 1 区当たり 40 個体調査した

$\mathrm{R}$ ：抵抗性, $\mathrm{S}$ : 罹病性

表 3.「紫さやか」および比較品種の耐冷性現地選抜圃と標準圃場に括ける試験成績の比較（2015２017，3 カ年）

\begin{tabular}{|c|c|c|c|c|c|c|c|c|c|c|c|c|}
\hline \multirow[b]{2}{*}{ 品種名 } & \multicolumn{6}{|c|}{ 幕別町駒畠検定圃（a）: 低温区 } & \multicolumn{4}{|c|}{ 芽室町（b）: 標準区 } & \multicolumn{2}{|c|}{$\mathrm{a} / \mathrm{b}$ 比 $(\%)$} \\
\hline & $\begin{array}{l}\text { 主茎長 } \\
(\mathrm{cm})\end{array}$ & $\begin{array}{c}\text { 主茎節数 } \\
\text { (節) }\end{array}$ & $\begin{array}{l}\text { 萊数 } \\
(\text { 萊/株) }\end{array}$ & $\begin{array}{c}\text { 萊数対比 } \\
(\%)\end{array}$ & $\begin{array}{c}\text { 子実重 } \\
(\mathrm{kg} / 10 \mathrm{a})\end{array}$ & $\begin{array}{c}\text { 子実重対比 } \\
(\%)\end{array}$ & $\begin{array}{l}\text { 主茎長 } \\
(\mathrm{cm})\end{array}$ & $\begin{array}{c}\text { 主茥 } \\
\text { 節数 (節) }\end{array}$ & $\begin{array}{l}\text { 萊数 } \\
\text { (萊/株) }\end{array}$ & $\begin{array}{c}\text { 子実重 } \\
(\mathrm{kg} / 10 \mathrm{a})\end{array}$ & 萊数 & 子実重 \\
\hline 紫さやか & 72 & 13.0 & 43 & 96 & $277^{a}$ & 105 & 72 & 14.8 & 48 & 307 & 90 & 90 \\
\hline エリモショウズ & 73 & 13.0 & 45 & 100 & $265^{\mathrm{ab}}$ & 100 & 66 & 14.5 & 49 & 301 & 92 & 88 \\
\hline しゅまり & 73 & 12.9 & 37 & 82 & $221^{\mathrm{b}}$ & 83 & 69 & 14.8 & 45 & 277 & 83 & 80 \\
\hline
\end{tabular}

1 区 $7.9 \mathrm{~m}^{2}$, 乱塊法 3 反復, 栽植密度は $66 \times 20 \mathrm{~cm}, 2$ 本立て, 15,152 本 $/ 10 \mathrm{a}$ とした.

幕別町駒香の検定圃と芽室町に扔ける生育期間中の積算温度差は, 2015 年が $168^{\circ} \mathrm{C}, 2016$ 年が $149^{\circ} \mathrm{C}, 2017$ 年が $170^{\circ} \mathrm{C}$ であった（農研 機構メッシュ農業気象データ使用).

分散分析で年次と年次 $\times$ 品種の交互作用がない形質について，3 品種群の多重比較（Tukey-Kramer 法）を行い，有意差を数値の右上付 き文字（a,b）で示した.

表 4. 芽室圃場に抢ける「紫さやか」拈よび比較品種の収量および品質調査成績（2014～2016，3 3 年の試験の平均值）

\begin{tabular}{|c|c|c|c|c|c|c|c|c|c|c|c|c|}
\hline \multirow[b]{2}{*}{ 品種名 } & \multirow{2}{*}{\multicolumn{2}{|c|}{$\begin{array}{c}\text { 総重 子実重 } \\
(\mathrm{kg} / 10 \mathrm{a})\end{array}$}} & \multirow{2}{*}{$\begin{array}{c}\text { 子実重 } \\
\text { 対比 } \\
(\%)\end{array}$} & \multirow{2}{*}{$\begin{array}{c}\text { 子実重率 } \\
(\%)\end{array}$} & \multirow{2}{*}{$\begin{array}{l}\text { 百粒重 } \\
(\mathrm{g})\end{array}$} & \multirow{2}{*}{$\begin{array}{c}\text { 百粒重 } \\
\text { 対比 } \\
(\%)\end{array}$} & \multirow{2}{*}{$\begin{array}{c}\text { 屑粒率 } \\
(\%)\end{array}$} & \multicolumn{5}{|c|}{ 原粒種皮色 } \\
\hline & & & & & & & & 明度 & 色相 & （指数） & 彩度 & 色相角 \\
\hline 紫さやか & 528 & 311 & 104 & 59 & $15.2^{\mathrm{a}}$ & 114 & 4.3 & 29.6 & 16.3 & 8.1 & 18.2 & 26.0 \\
\hline エリモショウズ & 504 & 300 & 100 & 58 & $13.3^{\mathrm{b}}$ & 100 & 7.2 & 29.5 & 16.2 & 8.9 & 18.5 & 28.2 \\
\hline しゅまり & 509 & 281 & 94 & 55 & $14.2^{\mathrm{ab}}$ & 106 & 5.1 & 29.1 & 16.4 & 8.0 & 18.1 & 26.3 \\
\hline
\end{tabular}

1 区 $7.9 \mathrm{~m}^{2}$, 乱塊法 3 反復, 栽植密度は $66 \times 20 \mathrm{~cm}, 2$ 本立て, 15,152 本 $/ 10 \mathrm{a}$ とした.

原粒種皮色はコニカミノルタ社製 CR -5 (C 光源 $2^{\circ}$ 視野) による.

分散分析で年次と年次 $\times$ 品種の交互作用がない形質について, 3 品種群の多重比較（Tukey-Kramer 法）を行い，有意差を数値の右上付 き文字（a,b）で示した。

表 5. 芽室圃場において収穫した「紫さやか」抢よび比較品種の加工適性および官能評価調査成績（2014～2016，3 カ年の平均値）

\begin{tabular}{|c|c|c|c|c|c|c|c|c|c|c|c|c|c|}
\hline \multirow[b]{2}{*}{ 品種名 } & \multicolumn{5}{|c|}{ 粒あん色 } & \multirow[b]{2}{*}{$\begin{array}{c}\text { 煮熟増加比 } \\
(\%)\end{array}$} & \multirow[b]{2}{*}{$\begin{array}{c}\text { 製あん歩留 } \\
(\%)\end{array}$} & \multirow[b]{2}{*}{$\begin{array}{c}\text { 煮えむら率 } \\
(\%)\end{array}$} & \multirow[b]{2}{*}{$\begin{array}{c}\text { あん粒子径 } \\
(\mu \mathrm{m})\end{array}$} & \multicolumn{4}{|c|}{ 粒あんの官能評価 } \\
\hline & $\begin{array}{c}\text { 明度 } \\
\mathrm{L}^{*}\end{array}$ & $\begin{array}{c}\text { 色相 } \\
\mathrm{a}^{*}\end{array}$ & $\begin{array}{c}\text { (指数) } \\
\mathrm{b}^{*}\end{array}$ & $\begin{array}{c}\text { 彩度 } \\
\mathrm{C}^{*}\end{array}$ & $\begin{array}{c}\text { 色相角 } \\
\mathrm{h}^{\circ}\end{array}$ & & & & & 味 & 香り & 色 & $\begin{array}{l}\text { 皮の } \\
\text { 硬さ }\end{array}$ \\
\hline 紫さやか & 25.1 & 9.6 & $3.5^{\mathrm{a}}$ & 10.3 & $20.0^{\mathrm{a}}$ & 2.52 & 68.0 & 5.2 & $122^{\mathrm{a}}$ & 3.2 & 3.3 & $3.4^{\mathrm{a}}$ & $3.4^{\mathrm{a}}$ \\
\hline エリモショウズ & 23.9 & 11.0 & $5.3^{\mathrm{b}}$ & 12.2 & $25.1^{\mathrm{b}}$ & 2.51 & 66.9 & 5.8 & $117^{\mathrm{b}}$ & 3.0 & 3.0 & $3.0^{\mathrm{b}}$ & $3.0^{\mathrm{b}}$ \\
\hline しゅまり & 24.8 & 10.0 & $3.7^{\mathrm{ab}}$ & 10.7 & $20.0^{\mathrm{a}}$ & 2.51 & 66.7 & 5.9 & $119^{\mathrm{ab}}$ & 2.9 & 2.9 & $3.3^{\mathrm{ab}}$ & $3.0^{\mathrm{b}}$ \\
\hline
\end{tabular}

芽室町の 2014 年から 2016 年の生産物による.

煮熟方法はアズキ $300 \mathrm{~g}$ に $1500 \mathrm{ml}$ を加水し 65 分で煮熟後, 煮豆に $500 \mathrm{ml}$ 加水し撹挥した溶液を, $500 \mu \mathrm{m}$ の篩でこしあんと煮えむら に分離した。 こしあんの製餡歩留, 煮えむら率は乾物換算値。

粒あんの製造は煮豆 $150 \mathrm{~g}$ に砂糖 $47 \mathrm{~g}$ と塩 $0.3 \mathrm{~g}$ を加え 15 分加熱した.

粒あん色はコニカミノルタ社製 CR-5 (C 光源 $2^{\circ}$ 視野) による.

あん粒子径は島津製作所社製 SALD-2001による.

官能評価はパネラー4名で「エリモショウズ」を基準（3）とした. 各項目について5（優る）から 1 (劣る) で 5 段階評価した平均值. 分散分析で年次と年次 $\times$ 品種の交互作用がない形質について, 3 品種群の多重比較（Tukey-Kramer 法）を行い, 有意差を数值の右上付 き文字（a,b）で示した. 
表 6. 十勝地方, 2 地帯計 19 か所の圃場における現地栽培試験成績

\begin{tabular}{|c|c|c|c|c|c|c|c|c|c|c|c|c|c|c|c|c|}
\hline 地帯区分 & 品種名 & $\begin{array}{l}\text { 試験 } \\
\text { 年次 }\end{array}$ & $\begin{array}{l}\text { 試験 } \\
\text { 畨場数 }\end{array}$ & $\begin{array}{l}\text { 倒伏 } \\
\text { 程度 }\end{array}$ & $\begin{array}{c}\text { 主茎長 } \\
(\mathrm{cm})\end{array}$ & $\begin{array}{l}\text { 主茎 } \\
\text { 節数 } \\
\text { (節) }\end{array}$ & $\begin{array}{c}\text { 萊数 } \\
\text { (萊/株) }\end{array}$ & $\begin{array}{l}\text { 総重 } \\
(\mathrm{kg} /\end{array}$ & $\begin{array}{l}\text { 子実重 } \\
0 \text { a) }\end{array}$ & $\begin{array}{l}\text { 子実重 } \\
\text { 対比 } \\
(\%)\end{array}$ & $\begin{array}{c}\text { 百粒重 } \\
(\mathrm{g})\end{array}$ & $\begin{array}{l}\text { 百粒重 } \\
\text { 対比 } \\
(\%)\end{array}$ & $\begin{array}{l}\text { 煮熟 } \\
\text { 増加比 } \\
(\%)\end{array}$ & $\begin{array}{l}\text { 製あん } \\
\text { 歩留 } \\
(\%)\end{array}$ & $\begin{array}{l}\text { 煮え } \\
\text { 屯ら率 } \\
(\%)\end{array}$ & $\begin{array}{c}\text { あん } \\
\text { 粒子径 } \\
(\mu \mathrm{m})\end{array}$ \\
\hline \multirow{6}{*}{$\begin{array}{l}\text { 十勝中央部 } \\
\text { 早生・ } \\
\text { 中生種地帯 }\end{array}$} & 紫さやか & 2016 & 3 & 0.3 & 56 & 11.0 & 25 & 392 & 202 & 101 & 13.2 & 114 & 2.50 & 68.4 & 3.8 & 120 \\
\hline & & 2017 & 5 & 0.5 & 64 & 13.1 & 44 & 551 & 313 & 101 & 15.5 & 109 & 2.55 & 67.5 & 13.5 & 120 \\
\hline & & 平均 & 8 & 0.4 & 60 & 12.1 & 35 & 472 & 257 & 101 & 14.4 & 112 & 2.53 & 68.0 & 8.6 & 120 \\
\hline & エリモショウズ & 2016 & 3 & 1.3 & 59 & 11.7 & 24 & 345 & 199 & 100 & 11.6 & 100 & 2.48 & 66.0 & 7.9 & 116 \\
\hline & & 2017 & 5 & 1.6 & 63 & 12.7 & 39 & 536 & 309 & 100 & 14.2 & 100 & 2.51 & 67.6 & 13.1 & 115 \\
\hline & & 平均 & 8 & $1.5 * *$ & 61 & 12.2 & 32 & 440 & 254 & 100 & $12.9^{*}$ & 100 & 2.49 & 66.8 & 10.5 & $115^{* *}$ \\
\hline \multirow{6}{*}{$\begin{array}{l}\text { 十勝 } \\
\text { (中央部除く) } \\
\text { 早生種地帯 }\end{array}$} & 紫さやか & 2016 & 7 & 1.1 & 49 & 10.8 & 17 & 344 & 211 & 105 & 13.1 & 112 & 2.48 & 68.8 & 4.5 & 120 \\
\hline & & 2017 & 4 & 0.9 & 71 & 12.4 & 33 & 645 & 349 & 101 & 16.0 & 106 & 2.57 & 68.2 & 12.7 & 122 \\
\hline & & 平均 & 11 & 1.0 & 60 & 11.6 & 25 & 495 & 280 & 103 & 14.5 & 109 & 2.53 & 68.5 & 8.6 & 121 \\
\hline & エリモショウズ & 2016 & 7 & 2.0 & 45 & 10.9 & 18 & 326 & 202 & 100 & 11.7 & 100 & 2.49 & 69.3 & 4.1 & 115 \\
\hline & & 2017 & 4 & 2.5 & 73 & 13.1 & 39 & 694 & 347 & 100 & 15.1 & 100 & 2.58 & 69.6 & 10.8 & 118 \\
\hline & & 平均 & 11 & $2.3^{* *}$ & 59 & 12.0 & 28 & 510 & 274 & 100 & $13.4^{*}$ & 100 & 2.53 & 69.4 & 7.5 & $116^{* *}$ \\
\hline
\end{tabular}

1 区 $3.3 \mathrm{~m}^{2}$, 乱塊法 2 反復, 栽植密度は $66 \times 20 \mathrm{~cm}, 2$ 本立て, 15,152 本 $/ 10 \mathrm{a}$ とした.

地帯区分は「道産豆類地帯別栽培指針」(1993 年北海道農政部) による.

倒伏程度は無 0 , 微 0.5 , 少 1 , 中 2 , 多 3 , 甚 4 で評価した.

*,**はt 検定でそれぞれ $5 \%, 1 \%$ 水準で「紫さやか」と有意差があることを示す。

\section{引用文献}

農林水産省（2018）平成 30 年産大豆, 小豆, いんげん及びらっ かせい（乾燥子実）の作付面積. [http://www.maff.go.jp/j/ tokei/kouhyou/sakumotu/menseki/attach/pdf/index-21.pdf].

北海道農政部 (1993) 豆類地帯別栽培指針. [https://www.hro.or.jp/ list/agricultural/center/kenkyuseika/gaiyosho/h06gaiyo/1993061. $\mathrm{htm}]$.

北海道農政部 (2019) 北海道オープンデータ CC-BY4.0. [https:// creativecommons.org/licenses/by/4.0/deed.ja].

島田尚典（2009）道立農試集報 94: 55-62.
Suzuki, T., T. Yoshii, S. Fujita, H. Shimada, T. Takeuchi and N. Kondo (2013) Breed. Sci. 63: 353-357.

千葉一美（1987）道立農試集報 56: 1-7.

畑井朝子 (1987) 調理科学 20.4: 294-301.

藤田正平・村田吉平・島田尚典・青山 聡・千葉一美・松川 勲・白井滋久 - 三浦豊雄 - 越智弘明 - 近藤則夫 (2002) 道 立農試集報 82: $31-40$

藤田正平（2007）北海道立農試報告 115: 1-54.

村田吉平 - 成河智明 -千葉一美 - 佐藤久泰 - 足立大山・松川 勲（1985）道立農試集報 53: 103-113. 